\title{
VISUALLYCONOMIC.COM: KOLABORASI DATA DAN GRAFIK VISUAL
}

\author{
Danu Widhyatmoko \\ Visual Communication Design, School of Design, BINUS University \\ Jln. K.H. Syahdan No. 9, Palmerah, Jakarta Barat 11480 \\ danu@binus.edu
}

\begin{abstract}
Visuallyconomic.com is a website of collaboration between economic information data and visual graphics that present infographic which contains Indonesian economy. Paper began with the history of visuallyconomic.com. Then it discussed the roles undertaken by the visuallyconomic.com. Research used literature study method, and continued with reflective data analysis. By the end of the paper, paper showed a more comprehensive picture about visuallyconomic.com's activities such as a social project as well as the information container of Indonesia's economic development in the form of infographics.
\end{abstract}

Keywords: visuallyconomic.com, economic data, infographic

\begin{abstract}
ABSTRAK
Visuallyconomic.com adalah website kolaborasi antara data informasi ekonomi dan visual grafis yang menyajikan infografis terkait dengan perekonomian Indonesia. Tulisan ini diawali dengan sejarah perkembangan visuallyconomic.com. Lalu artikel membahas peran demi peran yang dijalankan website. Metode penelitian yang digunakan dalam tulisan ini adalah studi literatur yang dilanjutkan dengan analisis data reflektif. Hingga pada akhir tulisan bisa didapatkan gambaran yang lebih jelas mengenai aktivitas yang dijalankan sebagai proyek sosial sekaligus wadah informasi perkembangan ekonomi Indonesia dalam bentuk infografis.
\end{abstract}

Kata kunci: visuallyconomic.com, data ekonomi, infografis 


\section{PENDAHULUAN}

Visuallyconomic adalah website yang menyajikan infografis berupa informasi yang terkait dengan perekonomian Indonesia. Infografis tersebut disajikan secara gratis sepanjang untuk kepentingan nonkomesial, pendidikan, dan ilmu pengetahuan. Website ini adalah wujud nyata dari altruisme. Altruisme sendiri menurut Sears (1994) adalah satu tindakan yang didasarkan atas rasa sukarela untuk saling menolong/membantu orang lain tanpa mengharapkan keuntungan apapun, sebagai bentuk tindakan tanpa pamrih. Keinginan untuk saling berbagi pengetahuan, ilmu, dan informasi menjadi landasan pengembangan dari visuallyconomic.com. Dalam pelaksanaannya, walaupun pola yang dikembangkan tidak mencari keuntungan, konten yang dibagikan bukan berarti konten kelas dua. Tidak sama sekali, konten yang dibagi adalah konten-konten yang berkualitas, baik dari data yang disajikan maupun kualitas dari visual yang dihadirkan.

Tujuan penulisan ini adalah untuk memahami aktivitas yang dilakukan, juga konten yang dimiliki oleh visuallyconomic.com. Secara khusus, artikel mengangkat peran sosial serta desain komunikasi visual dalam mendukung tujuan awal dari hadirnya website terkait. Penulisan ini disusun menggunakan studi literatur dan analisis reflektif guna menghasilkan gambaran yang terjadi di masyarakat Indonesia.

\section{METODE}

Penulisan ini disusun menggunakan pendekatan studi literatur untuk mendapatkan data pendukung dan mencari kerangka teori guna menguatkan hasil penulisan. Kemudian setelah data didapatkan, analisis data refletif dilakukan. Analisis reflektif adalah metode analisis data yang berpedoman pada cara berpikir reflektif. Pada dasarnya metode ini adalah kombinasi yang kuat antara berpikir deduktif dan induktif atau dengan mendialogkan data teoretis dan data empiris secara kritis bolak-balik (Stain, 2002). Dengan metode analisis reflektif, penulis mencari makna yang terkandung dari hasil pengumpulan data yang telah dilakukan. Kemudian, hasil dibandingkan dengan literatur yang ada sesuai keadaan ataupun fenomena yang tertangkap. Sehingga, dapat diperoleh kesimpulan data yang rasional dan ilmiah.

\section{HASIL DAN PEMBAHASAN}

\section{Perjalanan Awal Visuallyconomic.com}

Media sosial adalah media interaksi mahadahsyat yang dapat menyatukan sekian gagasan menjadi realitas yang penuh manfaat. Begitu pun kisah awal yang menyertai kehadiran Visuallyconomic.com. Penulis merupakan follower Twitter dari Faisal Basri, seorang ekonom yang memiliki integritas keilmuan, kepakaran, serta moral yang tinggi. Membaca sekian tweet yang disajikan Faisal Basri, dan terkadang disertai infografis, menimbulkan ide kepada penulis untuk dapat mengemasnya kembali ke dalam satu tampilan yang memiliki standar visual yang terjaga. Tampilan tersebut lalu disatukan ke dalam satu tempat agar mudah untuk dicari/ditemukan kembali, dan secara tidak langsung menciptakan pusat informasi data ekonomi yang baik. Akhirnya penulis yang memiliki kompetensi di bidang desain komunikasi visual menghubungi Faisal Basri untuk menawarkan kolaborasi antarkeilmuan, yakni antara keilmuan ekonomi dengan desain komunikasi visual. Selanjutnya, pengembangan visuallyconomic dimulai pada awal April 2013. 
Pada pelaksanaannya visuallyconomic.com memilih untuk meminimalkan segala pengeluaran yang menyertai pengelolaan sebuah website. Untuk itu dipilih platform Content Management System (CMS) berbasis WordPress yang berada di WordPress.com. Selain minim biaya (bahkan gratis), faktor keamanan serta kemudahan dalam pemanfaatan juga telah teruji. Di samping itu, pilihan theme yang disajikan secara gratis pun sudah memiliki kualitas yang baik, sehingga tidak diperlukan pengembangan dari nol dalam pelaksanaanya. Dana yang dibutuhkan hanya dikeluarkan untuk pembelian domain visuallyconomic.com sebagai aset yang akan dikelola jauh ke depan. Nama domain itu sendiri berharga $\$ 18$ per tahun.

\section{Visuallyconomic.com Sebagai Bentuk Gerakan Sosial}

World Wide Web sebagai sebuah lingkungan informasi yang terbuka, fleksibel, dan dinamis memungkinkan manusia untuk mengembangkan orientasi pengetahuan yang baru dan juga terlibat dalam dunia demokratis tentang pembagian mutual dan pemberian kuasa yang lebih interaktif dan berdasarkan pada masyarakat. Dunia maya memberikan tempat pertemuan semu yang memperluas dunia sosial, menciptakan peluang pengetahuan baru, dan menyediakan tempat untuk berbagi pandangan secara luas (Levy, 1997).

World Wide Web dan jejaring sosial yang ada di dalamnya memberikan kemudahan untuk berlangsungnya pertukaran informasi. Keilmuan dan pengetahuan menjadi jauh lebih mudah untuk didistribusikan. Tiap individu memiliki kesempatan yang jauh lebih terbuka untuk belajar, mendapatkan ilmu juga untuk memberikan ilmunya ke orang lain. Hal tersebut mendasari pilihan dari visuallyconomic untuk memilih jaringan dunia maya sebagai media penyebaran informasi yang dimiliki. Selain itu, akses yang luas, potensi penyebaran pesan yang sedemikian dahsyat, efektivitas serta efisiensi yang terkandung di dalamnya juga memberikan nilai tambah yang positif.

Visuallyconomic adalah proyek sosial, berkegiatan dengan basis nirlaba. Objektif yang dimiliki adalah menyampaikan informasi ekonomi seluas-luasnya kepada masyarakat lewat visual yang mudah dipahami. Dengan demikian, masyarakat diharapkan memiliki pengetahuan yang lebih baik terhadap perekonomian yang berjalan di Indonesia. Lalu masyarakat luas diharapkan untuk turut menyebarkan kembali informasi tersebut dengan maksud dan niat yang sama. Begitu juga di dunia pendidikan, visuallyconomic mempersilakan konten di situs untuk digunakan seluas-luasnya, sebagai bahan ajar dan bahan diskusi serta sebagai pengetahuan yang mencerdaskan. Semangat sosial yang dimiliki sejalan dengan yang diutarakan oleh Yunus (2011), "Bisnis-bisnis sosial memberi setiap orang kesempatan untuk berperan serta dalam menciptakan macam dunia yang ingin kita lihat. Berkat konsep bisnis sosial, masyarakat tidak harus menyerahkan semua masalah ke tangan pemerintah (dan selanjutnya menghabiskan umur mereka untuk mencela pemerintah karena gagal memecahkan masalah-masalah).” Pada akhirnya langkah sederhana ini diharapkan, sedikitnya, dapat memberikan pencerahan bagi masyarakat luas.

Altruisme adalah dasar penting pembentukan dan operasi jejaring sosial. Altruisme dan imbal balik serta emosi positif seperti cinta dan kebahagiaan, sampai kadar tertentu penting bagi kemunculan dan ketahanan jejaring sosial. (Christakis \& Fowler, 2009). Altruisme turut bekerja di kegiatan ini. Lewat semangat yang sama, mereka yang memiliki minat serta gagasan yang sama turut meneruskan informasi yang dimiliki visuallyconomic. Mereka melakukan tanpa imbalan apapun, bergerak dengan semangat berbagi dan keinginan yang sama untuk membuat keadaan lebih baik, untuk menjaga harapan atas Indonesia.

\section{Pola Kerja Visuallyconomic.com}

Dua keilmuan saling berkolaborasi di proyek ini, keilmuan ekonomi dan keilmuan desain komunikasi visual. Sebuah pekerjaan akan memberikan hasil yang maksimal jika komponen yang terdapat di dalamnya terdiri dari individu-individu yang sesuai dengan kompetensi yang dimiliki. 
Bekerja secara berkolaborasi adalah pola kerja yang efektif dan efisien. Menurut Katz dan Martin (1997) berkolaborasi itu sendiri memberikan manfaat: terbukanya kesempatan untuk saling berbagi pengetahuan, keahlian dan teknik, terciptanya transfer pengetahuan dan keahlian, memperbesar kemungkinan terjadinya perkawinan silang dari berbagai keilmuan yang berdampak bertambahnya wawasan dan terciptanya perspektif baru, terbukanya peluang untuk mewujudkan persahabatan berbasis intelektual, dan produktivitas pekerjaan menjadi lebih efektif dan efisien.

Sesuai konsep dasar, website visuallyconomic adalah kolaborasi antara data ekonomi dengan visual grafis. Data ekonomi yang masih mentah dapat berasal dari rilis Bank Indonesia, Kementrian Keuangan, Badan Pusat Statistik, IMF, Bank Dunia, kemudian diolah oleh Faisal Basri menjadi informasi yang dapat 'dibaca' dengan lebih mudah. Setelah menjadi informasi, baru kemudian diolah menjadi info grafis yang mengedepankan visual sebagai cara untuk berkomunikasi.

\section{Kategorisasi dan Peta Situs}

Konten visuallyconomic.com terdiri dari: (1) Tentang Kami, berisi narasi serta deskripsi dari Visuallyconomic dan orang-orang yang berada di balik layar sekaligus bertanggung jawab atas isi konten yang dirilis; (2) Galeri, kumpulan seluruh infografis yang ditampilkan secara acak dalam format galeri; (3) Hubungi Kami, berisi form yang berfungsi sebagai sarana untuk menghubungi visuallyconomic; (4) Infografis, merupakan konten utama dari visuallyconomic, terdiri dari 28 kategori yang berasal dari kategori di bidang ekonomi.

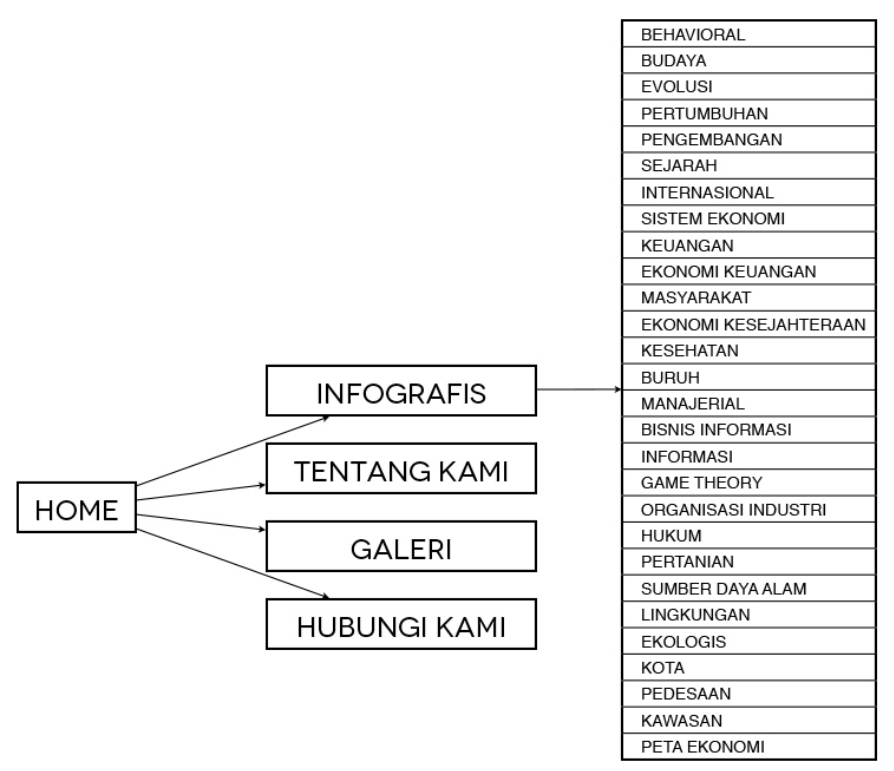

Gambar 1 Peta Situs

Selain konten tersebut, visuallyconomic.com juga ditambahkan dengan fitur mesin pencari, fitur arsip berdasarkan bulan, fitur untuk berlangganan berita lewat email dan juga narasi yang berisi sangkalan dan lisensi.

\section{Website Visuallyconomic.com}

Website visuallyconomic.com menggunakan theme gratis yang diberikan oleh WordPress.com, yakni Blissful Blog yang dikembangkan oleh Organic Themes. Tema Blissful Blog dirilis pada 25 Oktober 2012 dan telah digunakan lebih dari 46.000 blog. Tema ini dipilih karena sederhana, memiliki kualitas tipografi yang baik, header dan menu yang dapat dikustomisasi, fasilitas 
Full-Width Page Template (satu halaman penuh tanpa kolom samping), footer yang dapat dikustomisasi dengan widgets yang dipilih.

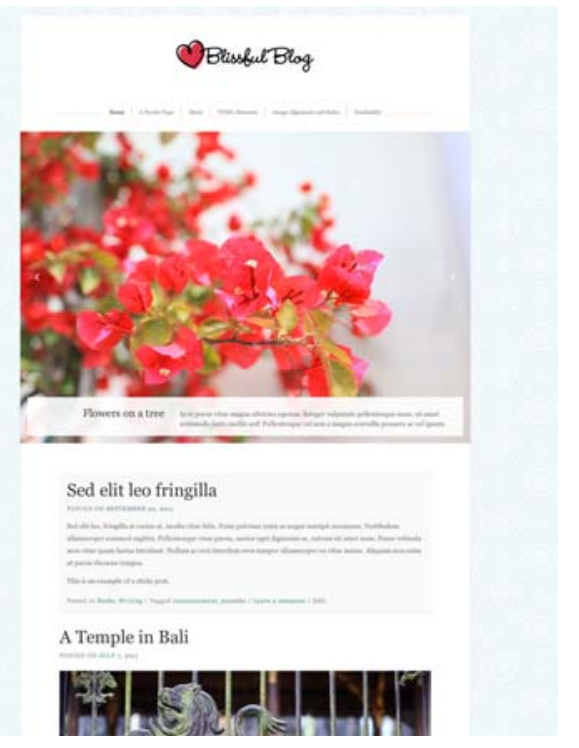

Gambar 2 Tampilan standar dari tema Blissful Blog

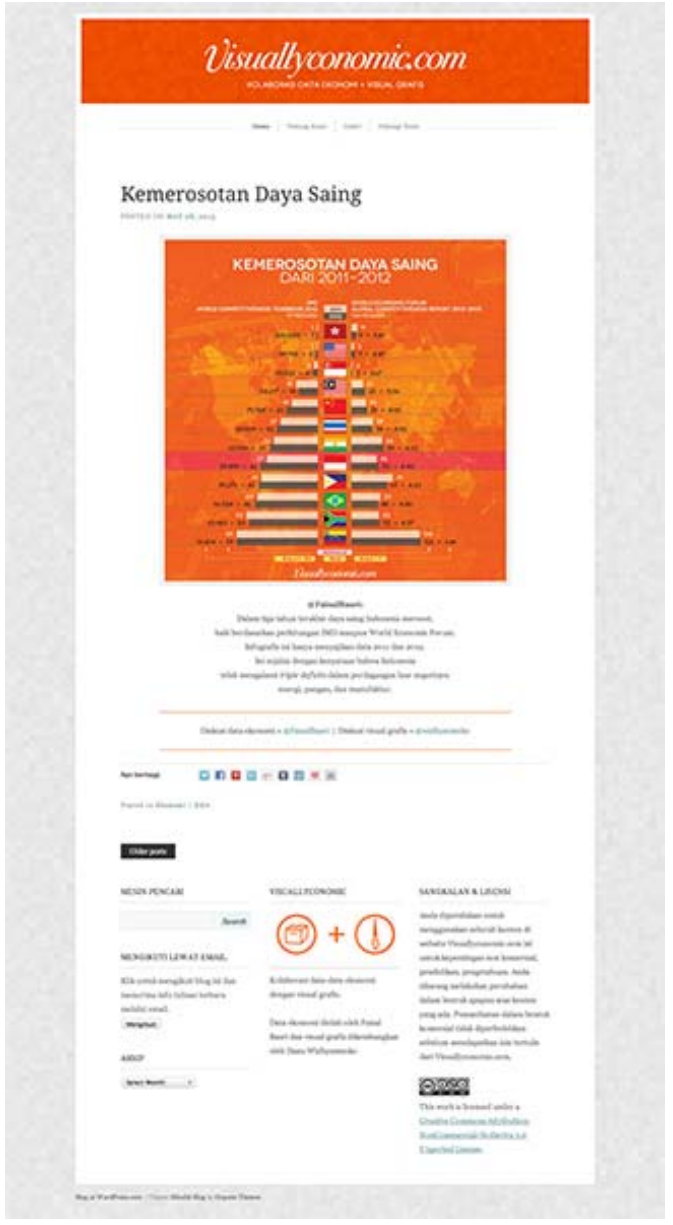

Gambar 3 Visuallyconomic.com dengan tema Bllisful Blog yang telah dikustomisasi 


\section{Elemen Grafis}

Elemen grafis pada website visuallyconomic, salah satunya adalah Identitas Visual yang berupa logo.

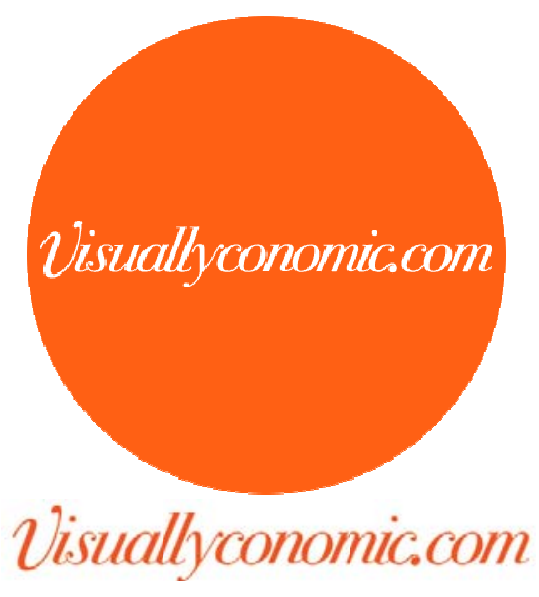

Gambar 4 Logo Visuallyconomic

Ikon yang digunakan di visuallyconomic.com merupakan icons yang dikembangkan oleh Picons. Ikon tersebut berbasis piktogram, bentuknya sederhana, jelas dalam bentuk yang disampaikan, unik, dan mudah untuk dikenali.

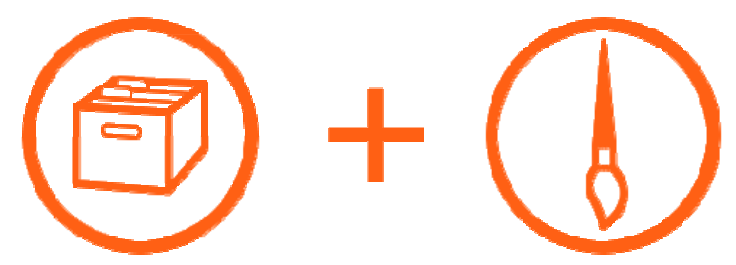

Gambar 5 Ikon yang digunakan di visuallyconomic.com

Background yang digunakan adalah sebagai berikut.
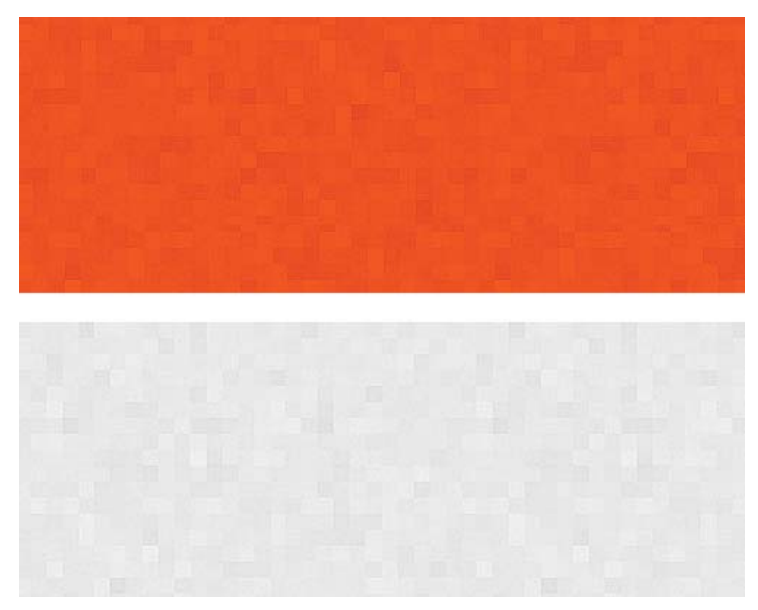

Gambar 6 Background website visuallyconomic.com 
Visuallyconomic menggunakan skema warna:

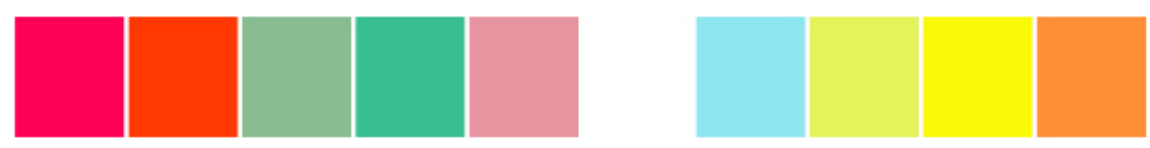

Gambar 7 Skema warna yang digunakan visuallyconomic

Warna yang digunakan mencerminkan kesegaran dan optimisme. Warna tersebut dipilih untuk memberikan inspirasi bagi mereka yang melihatnya. Seburuk apapun pesan/informasi yang disampaikan di dalam infografis tetap harus memberikan optimisme bagi siapa pun yang sedang menyimaknya.

\section{Infografis}

Infografis secara tradisional dipandang sebagai elemen visual yang dapat berupa tanda-tanda, grafik, ataupun diagram sebagai bentuk yang membantu pemahaman atas konten yang awalnya berupa teks (Ross, 2009). Lewat infografis yang baik, maka informasi yang ingin disampaikan menjadi lebih jelas, mudah untuk dipahami ketimbang deretan huruf saja. Dari infografis yang ada termungkinkan untuk menemukan sebab-akibat, guna melakukan analisis apa yang sedang terjadi, juga dapat memantau perubahan secara periodik. Selain itu, alasan menggunakan info grafis adalah sebuah gambar lebih bernilai dari seribu kata.

Jenis infografis yang kerap digunakan oleh visuallyconomic adalah Statistical Based InfoGraphics (Ross, 2009). Objektif yang dituju adalah bagaimana mengomunikasikan informasi yang kompleks dengan cepat dan jelas. Infografis Berbasis Statistik biasanya terdiri dari: Grafik, diagram, grafik, tabel, peta dan daftar urut; Grafik batang horisontal, grafik kolom vertikal, dan diagram lingkaran bulat/oval; Diagram dapat digunakan untuk menunjukkan cara sistem bekerja, dan dapat juga menjadi bagan organisasi yang menunjukkan jalur kewenangan, atau sistem diagram alur (flowchart) yang dapat menunjukkan gerakan atau tahapan secara berurutan; Tabel biasanya digunakan untuk data informasi yang mengandung banyak angka; Peta interaktif modern (Ross, 2009).

Beberapa infografis yang telah dirilis di visuallyconomic.com adalah sebagai berikut.

\section{Penerimaan vs Subsidi Minyak Indonesia 2012}

Pada infografis ini divisualkan perbandingan antara penerimaan dari minyak dengan subsidi BBM. Agar memudahkan pemaknaan pesan yang ingin disampaikan, maka digunakan visual timbangan yang secara jelas memperlihatkan ketidakseimbangan antara dua faktor yang telah disebutkan. Kemudian untuk memperjelas topik bahasan seputar minyak, pada infografis ditambahkan stilasi anjungan pengeboran minyak lepas pantai yang berfungsi sebagai tiang timbangan. 


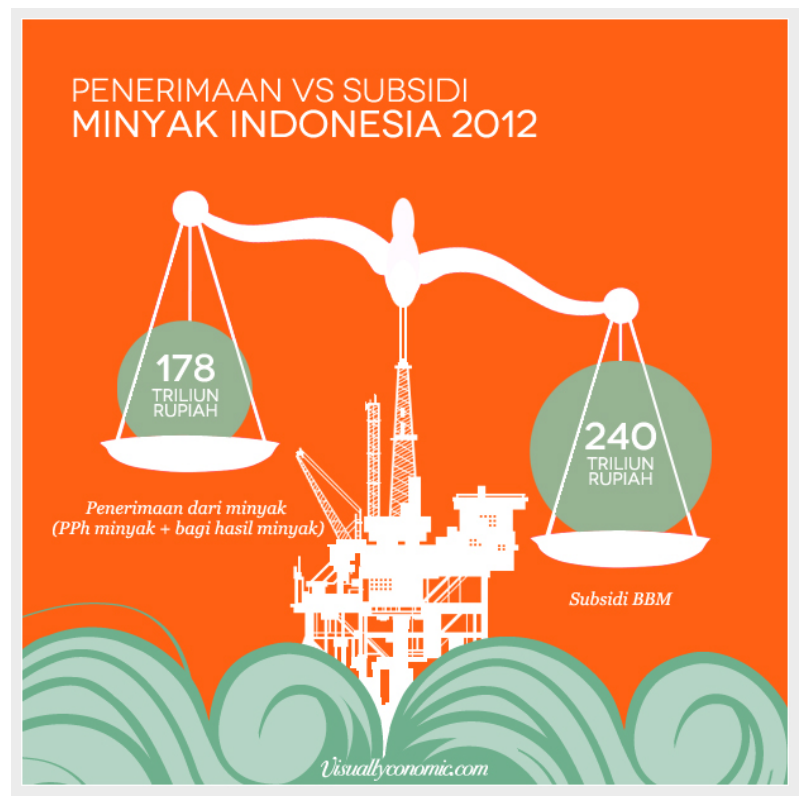

Gambar 8 Contoh infografis yang telah rilis di visuallyconomic.com:

Penerimaan vs Subsidi Minyak Indonesia 2012

\section{Kontribusi Devisa Tenaga Kerja Indonesia 2012}

Titik berat pada infografis ini adalah memperlihatkan jumlah tenaga kerja Indonesia yang bekerja di luar negeri sekaligus jumlah kontribusi finansial yang telah diberikan oleh mereka.

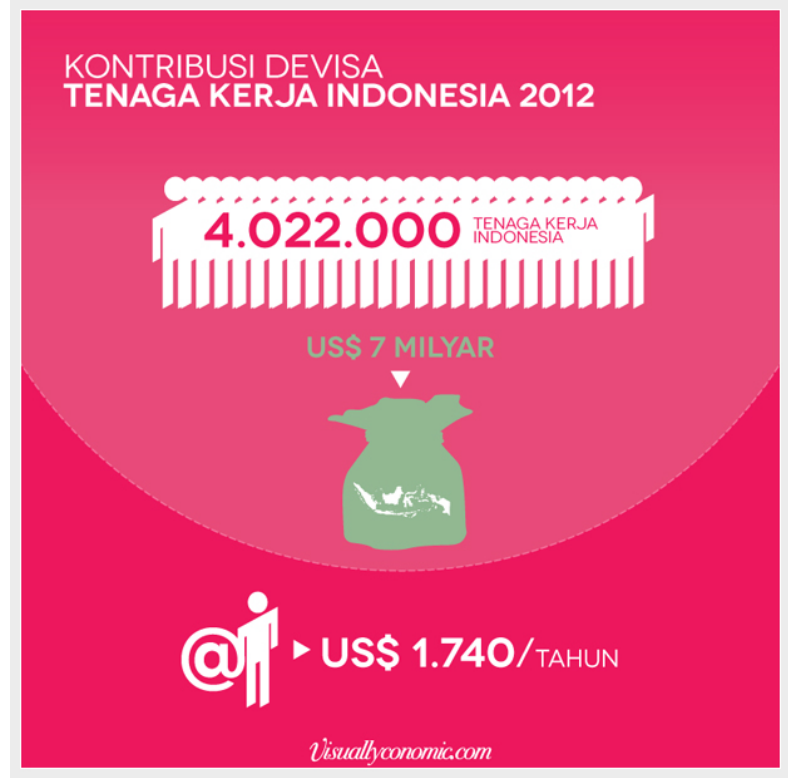

Gambar 9 Contoh infografis yang telah rilis di Visuallyconomic.com: Kontribusi Devisa Tenaga Kerja Indonesia 2012

Pekerja dan Pengangguran Indonesia Berdasarkan Tingkat Pendidikan

Tantangan visual yang didapatkan pada saat mengembangkan infografis ini adalah bagaimana menyajikan dua komponen (pekerja dan pengangguran) yang sedemikian besarnya untuk dapat 
berdampingan walau hanya dalam bentuk data saja. Informasi yang ingin ditekankan adalah pengangguran yang relatif rendah dan turun terus bisa merisaukan. Data mengindikasikan keadaan too poor to be unemployed. Dalam artian, makin rendah tingkat pendidikan, tak ada pilihan kecuali berkerja walaupun dengan upah rendah sekalipun (Basri, 2013).

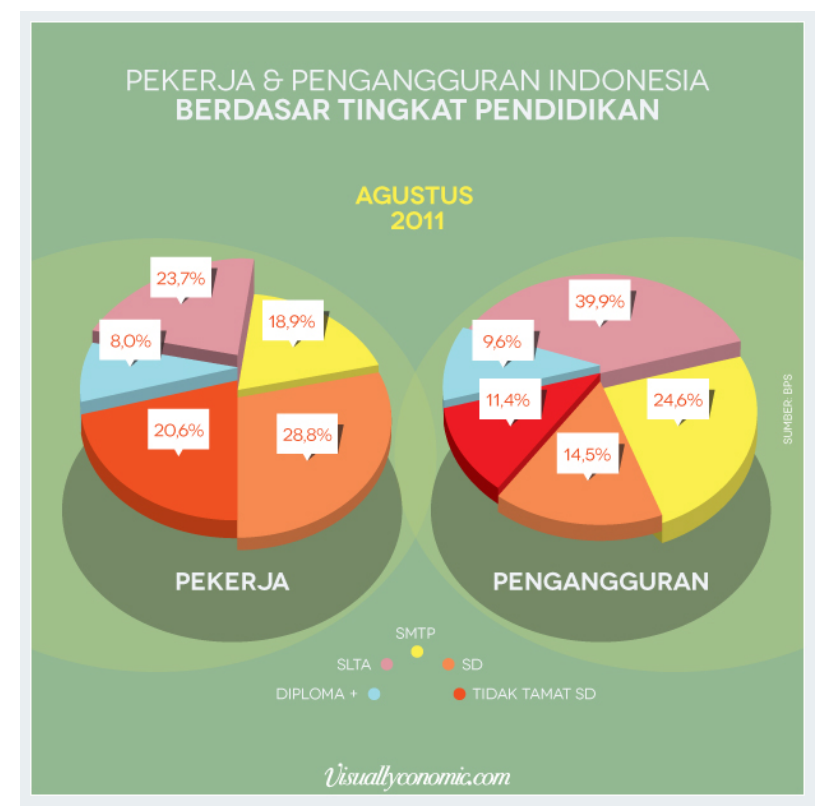

Gambar 10 Contoh infografis yang telah rilis di visuallyconomic.com: Pekerja dan Pengangguran Indonesia Berdasarkan Tingkat Pendidikan

\section{SIMPULAN}

Saling berbagi yang dilandasi kesamaan tujuan, minat, dan gagasan adalah pondasi kerja sama pada masa mendatang. Jaringan dunia maya yang telah hadir saat ini memungkinkan hal tersebut dapat dimanfaatkan dengan mudah. Namun untuk mewujudkannya tidak bisa lagi dilakukan secara pribadi alias tergantung hanya kepada satu-dua invidu saja, termasuk juga di dalammya, tidak memungkinan untuk dilakukan oleh satu keilmuan saja, dibutuhkan kolaborasi antarkeilmuan.

Kolaborasi antarkeilmuan akan menghasilkan karya yang hadir lewat proses yang efektif dan efisien. Itu disebabkan terbukanya kesempatan untuk saling berbagi pengetahuan hingga transfer pengetahuan pun dapat terjadi. Kemudian untuk mempercepat manfaat yang dihasilkan, dibutuhkan semangat peran serta berbasis sosial (nirlaba) yang bergerak dengan semangat berbagi dan keinginan yang sama untuk membuat keadaan lebih baik. Visuallyconomic hadir dengan semangat ingin berbagi, memanfaatkan kompetensi keilmuan yang dimiliki, lalu membagi informasi dan pengetahuan seluas mungkin dengan harapan memberikan manfaat bagi masyarakat dan akhirnya mencapai tujuan untuk membuat Indonesia yang lebih baik.

\section{DAFTAR PUSTAKA}

Christakis, N. A., Fowler, J. H. (2010). Zia Anshor (penerj.). CONNECTED - Dahsyatnya Kekuatan Jejaring Sosial Mengubah Hidup Kita. Jakarta: Gramedia Pustaka Utama. 
InstantShift. (2009). InfoGraphic Designs: Overview, Examples and Best Practices. Diakses 31 Mei 2013 dari http://www.instantshift.com/2009/06/07/infographic-designs-overview-examplesand-best-practices/

Katz, J., \& Martin, B. (1997) What is research collaboration? Research Policy, 26, 1-18.

Levy, P. (1997). Cyberculture. Paris: Editions Odile Jacob.

Sears, D. O., Peplau, L. A., \& Taylor, S. E. (1994). Social Psychology (8th Ed.). Englewood Cliffs, NJ: Prentice Hall.

Visuallyconomic. (2013). Kemiskinan, Pengangguran dan Pekerja Indonesia. Diakses 31 Mei 2013 dari http://visuallyconomic.com/2013/05/06/kemiskinan-pengangguran-dan-pekerjaindonesia/

Yunus, M. (2011). Alex Tri Kantjoro (penerj.). Bisnis Sosial: Sistem Kapitalisme Baru yang Memihak Kaum Miskin. Jakarta: Gramedia. 


\section{LAMPIRAN}

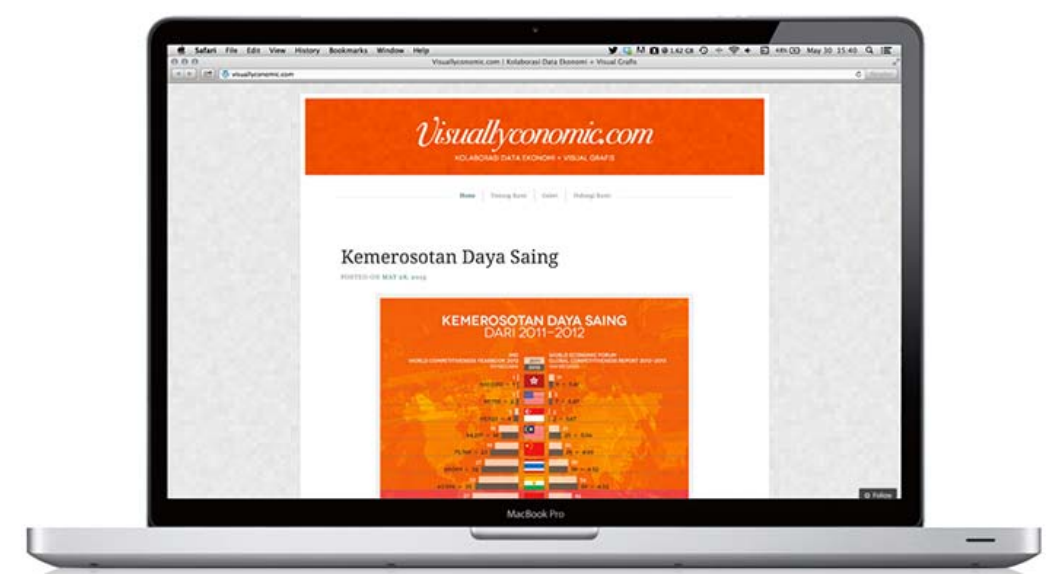

"Anda dipersilakan untuk menggunakan seluruh konten di website Visuallyconomic.com ini untuk kepentingan non komersial, pendidikan, pengetahuan. Anda dilarang melakukan perubahan dalam bentuk apapun atas konten yang ada. Pemanfaatan dalam bentuk komersial tidak diperbolehkan sebelum mendapatkan izin tertulis dari Visuallyconomic.com.” (Sangkalan \& Lisensi Visuallyconomic.com) 